\title{
7. APLIKACJE PFM JAKO FINTECH W FINANSACH OSOBISTYCH
}

(D) Krzysztof Waliszewski

Uniwersytet Ekonomiczny w Poznaniu

krzysztof.waliszewski@ue.poznan.pl

(iD) Anna Warchlewska

Uniwersytet Ekonomiczny w Poznaniu

anna.warchlewska@ue.poznan.pl

https://doi.org/10.18559/978-83-8211-083-8/7

\section{PFM applications as a FinTech in personal finance}

Abstract: Modern technologies play an increasingly important role in everyday life and, consequently, in planning and managing personal finances. The aim of the study is to assess the advantages and disadvantages as well as the opportunities and threats of using modern financial technologies in the process of managing personal finances. The chapter seeks to answer the research question whether the further development of the FinTech industry will influence the greater diversification of PFM applications in terms of functionality. The chapter consists of three main parts. The first presents the characteristics of PFM applications as a personal finance management tool. The second part provides a SWOT analysis of PFM. The chapter ends with a presentation of the results of primary and secondary research on the use of PFM applications and a conclusion.

Keywords: personal finance, modern financial technologies, PFM applications.

\subsection{Wstęp}

Jednym z najważniejszych obszarów decyzyjnych gospodarstwa domowego wpływających na stopień zaspokojenia jego potrzeb jest sfera finansowa, w której na co dzień podejmowane są decyzje dotyczące konsumpcji i oszczędzania, przeznaczania części oszczędności na inwestycje, źródeł finansowania potrzeb bieżących i mieszkaniowych, decyzje dotyczące zarządzania ryzykiem i ubezpieczeń, planowania emerytalnego i spadkowego, planowania podatkowego, kontroli przepływów pieniężnych i budżetu, a więc zarządzania płynnością finansową. Niski poziom wiedzy finansowej jest powodem relatywnie małego zainteresowania zarządzaniem finansami osobistymi, w tym planowaniem finansów osobistych. 
Decyzje finansowe podejmowane przez gospodarstwa domowe nie tylko wpływają na nie same, ale mają również znaczenie makroekonomiczne, kształtując konsumpcję, oszczędności, inwestycje i kredyt w gospodarce (Waliszewski, 2014).

Jednym z celów wykorzystania nowoczesnych technologii jest wspieranie procesów decyzyjnych konsumentów oraz dostosowanie nowoczesnych usług finansowych do zmieniających się potrzeb (Buettner, 2017; Nitin i in., 2019). Wdrożenie nowej ścieżki komunikacji z odbiorcą wymaga pogłębionych badań nad zachowaniami konsumentów, których znajomość jest niezbędna nie tylko w przypadku zrozumienia decyzji zakupowych, ale także w celu tworzenia produktów „szytych na miarę” oraz przewidywania przyszłej ewolucji decyzji klientów (Mazurek i Maz, 2019). Analiza postaw konsumentów znacząco wpływa na preferencje i dalsze przewidywania związane z osobowością użytkownika (Blackwell, Miniard i Engle, 2005). Ocena możliwości w procesie podejmowania decyzji finansowych (Beckett, Hewer i Howcroft, 2000) jest procesem wieloetapowym, na który składa się (a) kształtowanie opinii o możliwych sposobach zaspokajania potrzeb, (b) kształtowanie postaw wobec nich oraz (c) finalne dokonanie zakupu. Schemat ten czerpie z wcześniej zgromadzonych informacji i doświadczeń.

Wdrożenie nowoczesnych technologii w procesie zarządzania finansami osobistymi niesie ze sobą szereg wyzwań w obszarze obiegu i analizy danych, digitalizacji i automatyzacji procesów manualnych oraz architektury big data (Waliszewski i Warchlewska, 2020a). Nowoczesne technologie odgrywają coraz większą rolę w codziennym życiu, a co za tym idzie również w planowaniu i zarządzaniu finansami osobistymi, które są rozumiane jako realizacja celów wyznaczonych przez gospodarstwa domowe poprzez racjonalne wykorzystanie dostępnych na rynku rozwiązań finansowych. Proces ten jest wspomagany przez aplikacje mobilne i internetowe. Coraz więcej instytucji rynku finansowego zaczyna traktować innowacyjność jako jedną z głównych metod budowania przewagi konkurencyjnej. W segmencie usług podmiotów FinTech na uwagę zasługują między innymi aplikacje wspomagające zarządzanie budżetem domowym (Personal Finance Management, PFM).

Celem tego rozdziału jest ocena zalet i wad oraz szans i zagrożeń płynących z wykorzystania nowoczesnych technologii finansowych w procesie zarządzania finansami osobistymi. Dąży się do odpowiedzi na pytanie badawcze, czy dalszy rozwój branży FinTech wpłynie na większą dywersyfikację aplikacji PFM w zakresie funkcjonalności. Rozdział składa się trzech głównych części. Pierwsza z nich przedstawia charakterystykę aplikacji PFM jako narzędzia wspomagającego zarządzanie finansami osobistymi. W części drugiej dokonano analizy SWOT aplikacji PFM. Rozdział kończy prezentacja wyników badań pierwotnego i wtórnych w zakresie wykorzystania aplikacji PFM oraz podsumowanie. 


\subsection{Nowoczesne technologie w finansach osobistych}

Nowoczesne technologie przyczyniają się do zwiększenia efektywności funkcjonowania gospodarstwa domowego. Dzięki nim członkowie gospodarstw domowych są w stanie racjonalnie wykorzystywać swój czas, doskonalić umiejętności zarządzania finansami oraz podejmować optymalne decyzje finansowe. $Z$ drugiej strony bezkrytyczne poddawanie się nowinkom technologicznym (informacja, komunikacja) może prowadzić do negatywnych konsekwencji (Włodarczyk-Śpiewak, 2011). Duży postęp technologiczny społeczeństwa oraz instytucji finansowych może wpłynąć na samowykluczenie osób nieradzących sobie z obsługą elektronicznych i mobilnych narzędzi. Ważne zatem wydają się różnego rodzaju aplikacje, które ułatwiają zarządzanie finansami osobistymi i planowanie wydatków (Cichowicz, 2016).

Rozwój nowoczesnych technologii znajduje zastosowanie w obszarze detalicznych usług finansowych. Na rynku usług finansowych pojawił się nowy segment określany mianem technologii finansowych (FinTech), obejmujący start-upy niepodlegające tak restrykcyjnym regulacjom jak tradycyjne instytucje finansowe, z bardziej elastyczną ofertą dostępną dla klientów w mobilnych kanałach dystrybucji (Gawron, 2019). Najważniejsze zastosowania FinTech dotyczą obszaru finansowania, zarządzania aktywami, w tym robodoradztwa i aplikacji PFM, płatności oraz innych segmentów, na przykład ubezpieczeń. Sektor FinTech rozwija się wraz z wejściem na rynek usług finansowych młodych konsumentów. Nie są oni przywiązani do tradycyjnych banków i cenią sobie elastyczną, wygodną i oszczędzającą czas obsługę. FinTech oznacza wykorzystanie technologii do dostarczania konsumentom usług i produktów finansowych w zakresie bankowości, ubezpieczeń i inwestowania (Madir, 2019).

Należy zaznaczyć, że działalność podmiotów FinTech jest oparta na perspektywie funkcjonalnej, która różni się od perspektywy instytucjonalnej postrzegającej FinTech jako specyficzny rodzaj przedsiębiorstw typu start-up. Ta funkcjonalna perspektywa otwiera widok na trzy podobszary FinTech: InsurTech, związany $\mathrm{z}$ wykorzystaniem technologii finansowych w sektorze ubezpieczeniowym, RegTech, czyli wykorzystanie technologii finansowych do przestrzegania regulacji, oraz BankTech, czyli decyzje konsumenckie w bankowości detalicznej i platformy robodoradztwa. PFM i robodoradztwo są częścią decyzji konsumenckich w bankowości detalicznej, która wykorzystuje technologie finansowe (Waliszewski i Warchlewska, 2020b).

Istotną rolę w rozwoju rynku FinTech odgrywają banki, podmioty międzybankowe i inne instytucje finansowe. Poza innowacyjnością, elementami przewagi konkurencyjnej podmiotów z branży FinTech są uproszczone procedury, relatywnie niskie prowizje oraz nowoczesne rozwiązania technologiczne. Rozwój potencjału nowoczesnych rozwiązań wymaga odpowiedniej skali zaufania 
biznesowego i konsumenckiego - te elementy są w posiadaniu banków. Banki dostrzegają obecnie potrzebę współpracy przy wdrażaniu innowacji technologicznych (Górna i Warchlewska, 2018). Zaufanie, a więc oczekiwanie wiarygodności słowa, obietnicy, ustnego lub pisemnego przyrzeczenia innego podmiotu lub grupy, w przypadku sektora FinTech są tym bardziej istotne, że funkcjonuje on głównie w świecie wirtualnym (Świeszczak, 2017).

Co ważne, zasadą działania podmiotów FinTech jest wprowadzanie innowacji technologicznych z zewnątrz do wewnątrz, a nie z wewnątrz na zewnątrz. Oznacza to, że wdrażanie innowacyjnych zmian jest podporządkowane przede wszystkim usuwaniu negatywnych i kreowaniu pozytywnych doświadczeń klientów, które powstają w trakcie korzystania z usług firmy. Pojawienie się podmiotów FinTech jest odpowiedzią na luki powstałe w ofercie produktowej i usługach świadczonych przez tradycyjne podmioty. Odbiorcy usług finansowych oczekują od instytucji finansowych szybkiego dostosowania produktów i usług do indywidualnych, często zmieniających się potrzeb (Milic-Czerniak, 2019). Obecnie szerokie zainteresowanie firm FinTech rynkiem płatniczym i zarządzaniem finansami wynika przede wszystkim z wcześniejszych zaniedbań banków w rozwoju tego obszaru (Warchlewska i Waliszewski, 2020).

Rynek aplikacji PFM (Personal Finance Management) jest podzielony na aplikacje oferowane przez instytucje finansowe z sektora bankowego oraz aplikacje oferowane przez podmioty zewnętrzne (pozabankowe, społecznościowe) (rysunek 7.1).
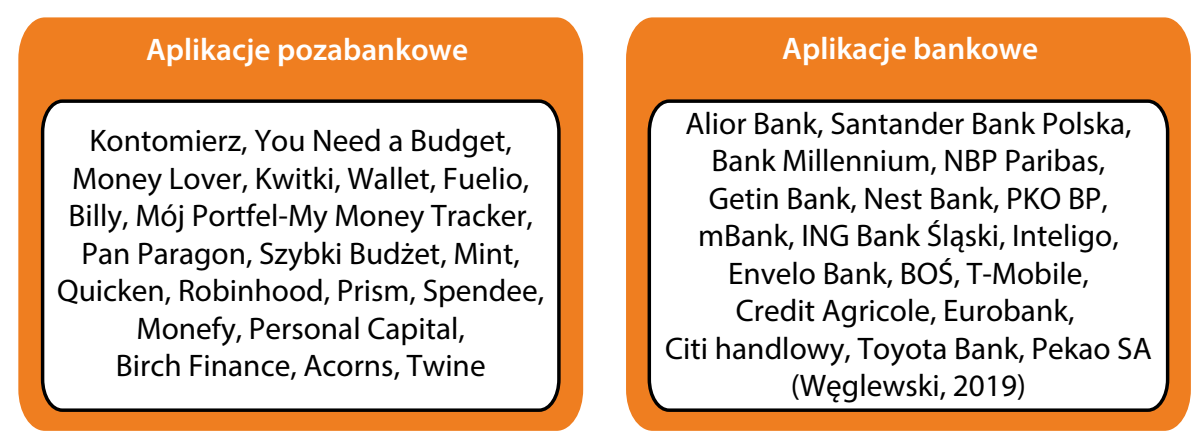

Rysunek 7.1. Wybrane aplikacje PFM w Polsce na świecie Źródło: opracowanie własne.

W literaturze przedmiotu zdefiniowano kryteria oceny jakości aplikacji finansowych (mobilnych i serwisów internetowych). Do najważniejszych obszarów należą: funkcjonalność, niezawodność i użyteczność. Funkcjonalność rozumiana jest jako dostępność funkcji, która może być mierzona za pomocą zdefiniowanych 
wymagań, zdolność do interakcji z innymi systemami, zachowanie standardów bezpieczeństwa oraz dokładność osiąganych wyników. Niezawodność to zdolność witryny lub aplikacji do sprawnego działania w określonych warunkach; charakteryzuje się ona między innymi tolerancją na błędy, zdolnością witryny do powrotu do normalnego działania oraz częstotliwością awarii. Z kolei użyteczność jest rozumiana jako dokładność konstrukcji interfejsu użytkownika, która spełnia wymogi efektywności, satysfakcji, zapamiętywalności, odporności na błędy i szybkości uczenia się (Nielsen, 2012).

\subsection{Analiza SWOT aplikacji PFM}

Charakterystykę aplikacji PFM dopełnia analiza SWOT przeprowadzona na potrzeby tego rozdziału. Wyniki tej analizy zaprezentowano w tabeli 7.1.

Obecne na światowych rynkach aplikacje mobilne pomagające zarządzać finansami osobistymi są skierowane szczególnie do młodego pokolenia, które wkracza w dorosłość. Charakteryzują się one nowoczesnym podejściem pod względem graficznym, funkcjonalnym oraz dostępnością dla smartfonów różnych generacji. Aplikacje pozwalają na gromadzenie informacji o promocjach i programach lojalnościowych oraz kontrolowanie wydatków. Cechuje je intuicyjność.

Aplikacje PFM łączy niewątpliwie wymiar praktyczny, co w przypadku finansów jest niezwykle istotne. Pozytywnie należy ocenić ogólną dostępność oraz duży wybór bezpłatnych aplikacji. Sektor finansowy stoi w obliczu zmian, które wynikają z rozwoju technologicznego (Omarini, 2018). Wdrażanie zaawansowanych systemów informatycznych, obsługi zdarzeń biznesowych oraz gromadzenia i przetwarzania danych jest dla sektora bankowego szansą na poprawę rentowności i relacji z klientami. Należy zwrócić uwagę, że twórcy dostępnych aplikacji na rynku konkurują że sobą pod względem użyteczności swoich programów oraz ich funkcjonalności. Aplikacje PFM są oceniane głównie pod kątem ich aktywacji oraz dostępności dla konsumenta, przyjazności interfejsu i nawigacji, podstawowych operacji finansowych oraz dodatkowych funkcjonalności (Waliszewski i Warchlewska, 2020c).

Tabela 7.1. Analiza SWOT aplikacji PFM

\begin{tabular}{|c|c|}
\hline Mocne strony & Slabe strony \\
\hline $\begin{array}{l}\text { - } \text { nowoczesność } \\
\text { - funkcjonalność } \\
\text { - dostępność } \\
\text { - bezpłatność (w przeważającej większości) } \\
\text { - wygoda }\end{array}$ & $\begin{array}{l}\text { - niekompatybilność systemów operacyjnych } \\
\text { - brak aplikacji mobilnych (tylko dostępność } \\
\text { w wersji komputerowej) }\end{array}$ \\
\hline
\end{tabular}


Tabela $7.1-\mathrm{cd}$.

\begin{tabular}{|c|c|}
\hline Szanse & Zagrożenia \\
\hline $\begin{array}{l}\text { - wzrost poziomu wiedzy ekonomiczno-finan- } \\
\text { sowej społeczeństwa } \\
\text { - większa chęć gospodarstw domowych do } \\
\text { planowania i kontroli budżetu domowego } \\
\text { z wykorzystaniem aplikacji PFM } \\
\text { - dyrektywa PSD2 - agregacja rachunków } \\
\text { z różnych banków }\end{array}$ & $\begin{array}{l}\text { - konkurencja pomiędzy fintechami } \\
\text { - konkurencja pomiędzy fintechami a bankami } \\
\text { - bezpieczeństwo danych }\end{array}$ \\
\hline
\end{tabular}

Źródło: opracowanie własne.

\section{Mocne strony}

Do mocnych stron aplikacji PFM można zaliczyć dostępność usług w każdym czasie i miejscu, 24/7, co wpływa na oszczędność czasu konsumenta. Zarządzanie finansami online wydaje się również wygodne $\mathrm{z}$ uwagi na obsługę aplikacji w sposób mobilny lub z wykorzystaniem komputera. Aplikacje PFM poprzez szereg funkcjonalności, na przykład import i eksport danych, bardzo szczegółową kategoryzację wydatków, wskazanie celów finansów, różne sposoby planowania wydatków oraz łączenie usług z różnych banków, wpływają na rosnącą popularność zdalnych narzędzi wspomagających zarządzanie finansami. Co istotne, analizowane aplikacje są w większości bezpłatne, co daje szansę na dotarcie do szerokiego grona odbiorców.

\section{Słabe strony}

Nie wszystkie aplikacje PFM mają technologiczną możliwość ich dualnego wykorzystania. Zdarza się, że użytkownik musi zdecydować, czy do obsługi PFM będzie wykorzystywać tylko komputer, czy tylko smartfon. Należy również mieć na uwadze utrudnienia $\mathrm{w}$ zakresie instalacji aplikacji z wykorzystaniem różnych systemów operacyjnych.

\section{Szanse}

Do szans rynkowych aplikacji PFM należy zaliczyć otwartość społeczeństwa w różnych grupach wiekowych na nowe kanały kontaktu z bankiem oraz wzrost poziomu wiedzy ekonomicznej, finansowej społeczeństwa. Większa pewność w zarządzaniu finansami przekłada się na większą chęć gospodarstw domowych do planowania i kontroli budżetu domowego. Ponadto implementacja Dyrektywy PSD2 pozwala konsumentowi na dokonanie wyboru najlepszej usługi finansowej oraz agregację danych z różnych banków w jednej aplikacji. 


\section{Zagrożenia}

Bardzo duża liczba dostępnych aplikacji PFM na rynku może stać się powodem trudności decyzyjnych, które narzędzie wybrać. Szeroki wachlarz dostępnych aplikacji bankowych i niebankowych (fintechów) często budzi wątpliwości konsumentów, z której aplikacji korzystać oraz czy wybrać tylko jedno, czy wiele rozwiązań. Zagrożeniem w zakresie aplikacji PFM staje się również ochrona danych oraz zapewnienie bezpieczeństwa danych.

\subsection{Przegląd badań na temat aplikacji PFM}

\subsubsection{Wyniki badań wtórnych}

Sektor finansowy stoi w obliczu zmian wynikających z rozwoju technologii. Wdrożenie zaawansowanych systemów informatycznych, kreowanie zdarzeń gospodarczych oraz gromadzenie i przetwarzanie danych jest szansą dla branży bankowej, by poprawić rentowność oraz udoskonalić relacje z klientami. Niezbędna jest również współpraca w wykorzystaniu PFM świata biznesu i nauki, czego dowodzą poczynione już badania w przedmiotowym zakresie. Ich syntetyczny opis prezentuje tabela 7.2. Od 2012 roku obserwuje się intensyfikację działań badawczych w zakresie poznawczym zarówno zachowań konsumentów, jak i wykorzystywanych narzędzi wspomagających proces zarządzania finansami osobistymi z punktu widzenia kryteriów ich oceny przez użytkowników.

Tabela 7.2. Wybrane badania dotyczące PFM w literaturze polskiej i światowej

\begin{tabular}{|c|l|l|l|}
\hline Lata & $\begin{array}{l}\text { Autor badania/ } \\
\text { raportu }\end{array}$ & Przedmiot badania & \multicolumn{1}{|c|}{ Glówne wnioski z badania } \\
\hline 2009 & $\begin{array}{l}\text { F. Philip, M. } \\
\text { James, E. Joor- } \\
\text { gen; Cisco In- } \\
\text { ternet Business } \\
\text { Solution Group } \\
\text { (IBSG) }\end{array}$ & $\begin{array}{l}\text { Priorytety finansowe } \\
\text { wobec usług banko- } \\
\text { wych oraz preferowane } \\
\text { form kontaktu klienta } \\
\text { z bankiem }\end{array}$ & $\begin{array}{l}\text { Konsumenci aktywni finansowo oraz ko- } \\
\text { rzystający z aplikacji PFM rzadko migru- } \\
\text { ją z banku do banku. Mają wyższe salda } \\
\text { rachunków bankowych oraz wykorzystują } \\
\text { większy zakres produktów i usług }\end{array}$ \\
\hline $\begin{array}{l}\text { Raport z bada- } \\
\text { nia NBP }\end{array}$ & $\begin{array}{l}\text { Funkcjonalności apli- } \\
\text { kacji PFM }\end{array}$ & $\begin{array}{l}\text { Największą zaletą internetowych serwi- } \\
\text { sów ułatwiających prowadzenie budżetu } \\
\text { domowego jest ich niezależność od ban- } \\
\text { ków. Użytkownik może powiązać kilka } \\
\text { rachunków bankowych na jednym serwi- } \\
\text { sie. Wątpliwe jest dla celów przejrzysto- } \\
\text { ści planowania budżetu wykorzystywanie } \\
\text { tylko aplikacji finansowych na smartfonie }\end{array}$ \\
\hline
\end{tabular}


Tabela $7.2-$ cd.

\begin{tabular}{|c|c|c|c|}
\hline Lata & $\begin{array}{l}\text { Autor badania/ } \\
\text { raportu }\end{array}$ & Przedmiot badania & Glówne wnioski $\mathrm{z}$ badania \\
\hline 2012 & $\begin{array}{l}\text { Employee Be- } \\
\text { nefit Research } \\
\text { Institute and } \\
\text { Mathew Gre- } \\
\text { enwald \&As- } \\
\text { sociates,Inc. } \\
\text { Retirement }\end{array}$ & $\begin{array}{l}\text { Jak konsumenci zarzą- } \\
\text { dzają swoimi finansami } \\
\text { online? (analiza wygo- } \\
\text { dy korzystania) }\end{array}$ & $\begin{array}{l}\text { Tylko niewielka część konsumentów } \\
\text { w wieku produkcyjnym i poprodukcyj- } \\
\text { nym pozytywnie ocenia wykorzystanie } \\
\text { technologii internetowych do zarządzania } \\
\text { swoimi finansami. Wśród aktywnych } \\
\text { użytkowników serwisów } 4 \text { na } 10 \text { pra- } \\
\text { cowników oraz } 1 / 3 \text { emerytów deklaruje, } \\
\text { że bardzo dobrze czuje się w prowadzeniu } \\
\text { rozliczeń poprzez kalkulatory online. } \\
\text { Mniejsze zainteresowanie obserwuje się } \\
\text { w obszarze porad specjalistów drogą } \\
\text { online }\end{array}$ \\
\hline 2012 & $\begin{array}{l}\text { Marta Musiał } \\
\text { Uniwersytet } \\
\text { Szczeciński }\end{array}$ & $\begin{array}{l}\text { W jakim stopniu pol- } \\
\text { skie gospodarstwa } \\
\text { domowe wykorzystują } \\
\text { podstawowe narzędzia } \\
\text { zarządzania finansami } \\
\text { osobistymi? }\end{array}$ & $\begin{array}{l}\text { Polskie gospodarstwa domowe w małym } \\
\text { zakresie stosują narzędzia gospodarowa- } \\
\text { nia finansami osobistymi. Najpopular- } \\
\text { niejszym narzędziem jest jednak budżet } \\
\text { domowy sporządzany w formie tradycyj- } \\
\text { nej (karta i papier). Wskazano zależność } \\
\text { pomiędzy stosowaniem narzędzi zarzą- } \\
\text { dzania finansami osobistymi i wyksztal- } \\
\text { ceniem (odsetek osób wykorzystujących } \\
\text { owe narzędzia wzrasta wraz ze wzrostem } \\
\text { poziomu wykształcenia) }\end{array}$ \\
\hline 2013 & $\begin{array}{l}\text { Javelin Strategy } \\
\& \text { Research }\end{array}$ & $\begin{array}{l}\text { Badania oczekiwań } \\
\text { konsumentów wobec } \\
\text { PFM }\end{array}$ & $\begin{array}{l}\text { Respondenci w } 56 \% \text { zadeklarowali, że } \\
\text { byliby skłonni wykorzystywać narzędzia } \\
\text { PFM w swoim podstawowym rachunku. } \\
\text { Wykorzystanie narzędzi zdalnych wpłynie } \\
\text { na stały nadzór nad budżetem, pozwoli } \\
\text { na prognozowanie i planowanie. Ame- } \\
\text { rykańscy konsumenci zadeklarowali, że } \\
\text { chcieliby mięć możliwość agregowania } \\
\text { wszystkich danych finansowych w jednej } \\
\text { aplikacji. Banki powinny skupić uwagę na } \\
\text { personalizacji porad, alertów }\end{array}$ \\
\hline 2013 & $\begin{array}{l}\text { Adam Barem- } \\
\text { bruch Uniwer- } \\
\text { sytet Gdański }\end{array}$ & $\begin{array}{l}\text { Różnice między kla- } \\
\text { sycznymi a nowocze- } \\
\text { snymi narzędziami } \\
\text { zarządzania finansami } \\
\text { osobistymi. Wady } \\
\text { i zalety PFM }\end{array}$ & $\begin{array}{l}\text { Przewaga konkurencyjna banków, które } \\
\text { w Polsce już obecnie wdrażają systemy } \\
\text { PFM w ramach bankowości internetowej } \\
\text { może być zachwiana w sytuacji, gdy ofe- } \\
\text { rowane w ramach danego banku usługi } \\
\text { będą dotyczyć tylko produktów oferowa- } \\
\text { nych w ramach tego banku }\end{array}$ \\
\hline
\end{tabular}


Tabela $7.2-\mathrm{cd}$

\begin{tabular}{|c|c|c|c|}
\hline Lata & $\begin{array}{l}\text { Autor badania/ } \\
\text { raportu }\end{array}$ & Przedmiot badania & Główne wnioski z badania \\
\hline 2015 & $\begin{array}{l}\text { Viera Gafriko- } \\
\text { va, Wiesław } \\
\text { Szczesny, } \\
\text { Zdzisław } \\
\text { Odrzygóźdź }\end{array}$ & $\begin{array}{l}\text { Analiza wybranych } \\
\text { aplikacji PFM na } \\
\text { rynku polskim i za- } \\
\text { granicznym (ocena } \\
\text { wiarygodności } \\
\text { i funkcjonalności) }\end{array}$ & $\begin{array}{l}\text { Wskazuje się kilka czynników, które } \\
\text { mogą się przyczynić do rozwoju apli- } \\
\text { kacji PFM: wyniki ekonomiczne firm } \\
\text { oferujących narzędzia PFM, zachowania } \\
\text { finansowe konsumentów oraz podejście } \\
\text { do planowania finansów }\end{array}$ \\
\hline 2016 & $\begin{array}{l}\text { Marie Heikel- } \\
\text {-Elsabeh, } \\
\text { Sebastien } \\
\text { Nouet, } \\
\text { Maximillien } \\
\text { Nayaradou }\end{array}$ & $\begin{array}{l}\text { Wykorzystanie i zasto- } \\
\text { sowanie aplikacji PFM } \\
\text { do zarządzania finan- } \\
\text { sami osobistymi oraz } \\
\text { finansami firmy }\end{array}$ & $\begin{array}{l}\text { Wykorzystanie aplikacji PFM jest uza- } \\
\text { leżnione od celu i zastosowania narzędzi. } \\
\text { Konsumenci intensywniej korzystający } \\
\text { z rozwiązań mobilnych preferują wyko- } \\
\text { rzystanie aplikacji oferowanych przez } \\
\text { podmioty zewnętrzne zamiast aplikacji } \\
\text { bankowych. Użytkownicy podkreśla- } \\
\text { ją kompleksowość pozabankowych } \\
\text { narzędzi }\end{array}$ \\
\hline 2016 & $\begin{array}{l}\text { GfK Polonia dla } \\
\text { ING }\end{array}$ & $\begin{array}{l}\text { Zwyczaje finansowe } \\
\text { Polaków. Rola finan- } \\
\text { sów osobistych w po- } \\
\text { równaniu z innymi } \\
\text { ważnymi sferami życia }\end{array}$ & $\begin{array}{l}\text { Polacy są otwarci na nowe rozwiązania, } \\
\text { jeżeli mieliby narzędzie pomagające } \\
\text { w osiąganiu konkretnych celów finan- } \\
\text { sowych (na przykład oszczędzanie). } \\
\text { Wskazują na dużą przydatność zestawień } \\
\text { wydatków na dany miesiąc. Respondenci } \\
\text { traktują fakt analizowania wydatków } \\
\text { jako nieprzyjemny obowiązek }\end{array}$ \\
\hline 2017 & $\begin{array}{l}\text { Izba Gospodarki } \\
\text { Elektronicznej/ } \\
\text { Mobile Institute }\end{array}$ & $\begin{array}{l}\text { Portfel Polaka: Analiza } \\
\text { wydatków i sposobów } \\
\text { płatności }\end{array}$ & $\begin{array}{l}\text { Korzystanie z usług bankowych zade- } \\
\text { klarowało } 80 \% \text { internautów, w tym } 28 \% \\
\text { korzysta z klasycznego kanału zarządza- } \\
\text { nia kontem bankowym, } 36 \% \text { wybiera } \\
\text { serwis internetowy, } 36 \% \text { - serwis mobil- } \\
\text { ny banku. Polski konsument przedstawia } \\
\text { się jako pragmatyczny oraz otwarty na } \\
\text { innowacje uczestnik rynku finansowego }\end{array}$ \\
\hline $\begin{array}{l}2017- \\
2018\end{array}$ & $\begin{array}{l}\text { Agnieszka Sam- } \\
\text { sel Uniwersytet } \\
\text { Szczeciński }\end{array}$ & $\begin{array}{l}\text { Planowanie finansów } \\
\text { osobistych. Informacje } \\
\text { pozyskane od gospo- } \\
\text { darstw domowych }\end{array}$ & $\begin{array}{l}\text { Gospodarstwa domowe w przeważającej } \\
\text { części nie prowadzą budżetu domowe- } \\
\text { go (nie zarządzają w sposób planowy } \\
\text { uzyskiwanymi dochodami). Gospo- } \\
\text { darstwa domowe (osoba prowadząca/ } \\
\text { głowa rodziny) zadeklarowały, że mają } \\
\text { pod kontrolą swój budżet i nie widzą } \\
\text { konieczności regularnego planowania. } \\
\text { Ponadto, zdaniem badanych, zarządzenie } \\
\text { budżetem wymaga czasu - jest to czyn- } \\
\text { nik zniechęcający }\end{array}$ \\
\hline
\end{tabular}


Tabela $7.2-$ cd.

\begin{tabular}{|c|l|l|l|}
\hline Lata & $\begin{array}{c}\text { Autor badania/ } \\
\text { raportu }\end{array}$ & Przedmiot badania & \multicolumn{1}{c|}{ Główne wnioski z badania } \\
\hline 2018 & Aite Group & $\begin{array}{l}\text { Budowa/odbudowa } \\
\text { zarządzania finansami } \\
\text { osobistymi. Zadania } \\
\text { dla banków }\end{array}$ & $\begin{array}{l}\text { Około 75\% badanych w wieku 22-49 lat } \\
\text { potwiedza zainteresowanie korzystaniem } \\
\text { z wirtualnego trenera finansowego. Szan- } \\
\text { są dla banków jest wykorzystanie sztucz- } \\
\text { nej inteligencji do dostarczania narzędzi } \\
\text { wspomagających proces zarządzania fi- } \\
\text { nansami. Banki powinny dążý do imple- } \\
\text { mentacji interaktywnego narzędzia, które } \\
\text { pomoże konsumentowi przejąć kontrolę } \\
\text { nad jego kondycją finansową }\end{array}$ \\
\hline
\end{tabular}

Źródło: opracowanie własne na podstawie: (Farah, Macaulay i Ericsson, 2010; Uryniuk, 2012; RCS, 2012; Musiał, 2015; PFM na Zachodzie, 2017; Barembruch, 2013; Gafrikova, Szczesny i Odrzygóźdź, 2015; Haikel-Elsabeh i Nouet, 2016; Badanie Moje, 2016; Samsel, 2019; Albertazzi, 2018).

Kryteria oceny jakości aplikacji finansowych (mobilnych i internetowych) są następujące:

- funkcjonalność jest rozumiana jako dostępność funkcji, która może być mierzona za pomocą zdefiniowanych wymagań, zdolność do interakcji $\mathrm{z}$ innymi systemami, utrzymanie standardów bezpieczeństwa i dokładność osiąganych wyników;

- niezawodność to zdolność witryny lub aplikacji do efektywnego działania w określonych warunkach, która charakteryzuje się między innymi tolerancją na błędy, zdolnością witryny do powrotu do normalnego działania oraz częstotliwością występowania awarii;

- użyteczność jest rozumiana jako poprawność konstrukcji interfejsu użytkownika, na którą składają się efektywność, satysfakcja, zapamiętywalność, odporność na błędy i szybkość uczenia się.

\subsubsection{Wyniki badania pierwotnego}

Autorzy rozdziału przeprowadzili pierwsze w Polsce badanie użytkowników aplikacji PFM, którego celem była analiza jakości zastosowanych aplikacji PFM: funkcjonalność, niezawodność, użyteczność, wydajność, modyfikowalność, przenośność, oraz analiza wpływu COVID-19 na finanse osobiste: korzystanie $\mathrm{z}$ aplikacji w czasach dystansu społecznego i pracy zdalnej. Badanie miało charakter ogólnopolski i zostało przeprowadzone na grupie $N=301$ osób, z których 288 przyznało, że korzysta $\mathrm{z}$ aplikacji wspomagających zarządzanie budżetem, a 13 - że nie korzysta z takich aplikacji. Ankieta była dostępna na takich portalach 
finansowych jak Bankier.pl oraz na blogach o tematyce finansowej - między innymi Marcina Iwucia „Finanse bardzo osobiste” oraz Macieja Samcika „Subiektywnie o finansach". Badanie zostało przeprowadzone w okresie od 3 sierpnia 2020 roku do 31 sierpnia 2020 roku.

W badanej grupie przeważali mężczyźni (66,67\% badanych), a także osoby w wieku $26-35$ lat stanowiące $42,36 \%$. Osoby z wykształceniem wyższym stanowiły $74,65 \%$ grupy badanej. Pod względem sytuacji zawodowej przeważały osoby pracujące $(79,44 \%)$. Osoby badane mieszkały zazwyczaj w dużych miejscowościach powyżej 500 tys. mieszkańców $(41,61 \%)$, żyły zazwyczaj w gospodarstwach 2-4 osobowych i miały zazwyczaj duże dochody na osobę w tym gospodarstwie.

Badani w większości korzystali z aplikacji niebankowych (87,50\%), jedynie $12,5 \%$ ankietowanych korzystało z aplikacji bankowych. Najczęściej wymieniane były: Kontomierz (15,28\%), You Need a Budget YNAB $(15,28 \%)$, Arkusz kalkulacyjny $(9,38 \%)$, 1Money (6,94\%) i Family Finanse Trucker (6,60\%) (rysunek 7.2).

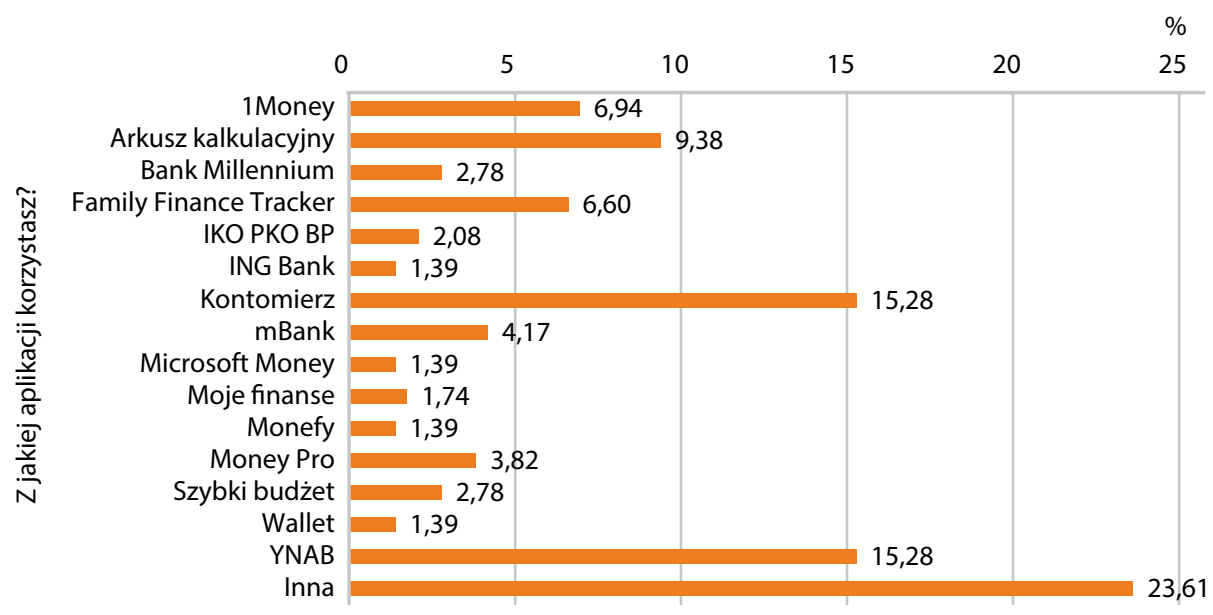

Rysunek 7.2. Rodzaj wykorzystywanej aplikacji

Ponad połowa osób $(54,32 \%)$ korzystała z aplikacji mobilnie oraz przez stronę www; a następne 36,69\% korzystało tylko z aplikacji mobilnej (rysunek 7.3).

Według zdecydowanej większości badanych osób zainstalowanie aplikacji było bardzo łatwe $(81,25 \%)$ (por. rysunek 7.4$)$.

Ponad połowa badanych osób oceniała aplikację, jakiej używała, jako przejrzystą $(50,17 \%)$, uporządkowaną $(56,60 \%)$ i zachęcającą do korzystania $(54,36 \%)$ (rysunek 7.5). 
$\%$

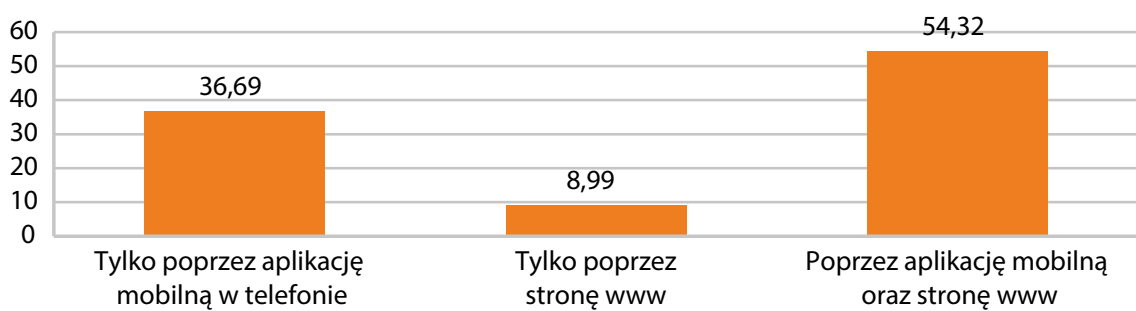

W jaki sposób możesz korzystać z aplikacji?

Rysunek 7.3. Sposób korzystania z aplikacji

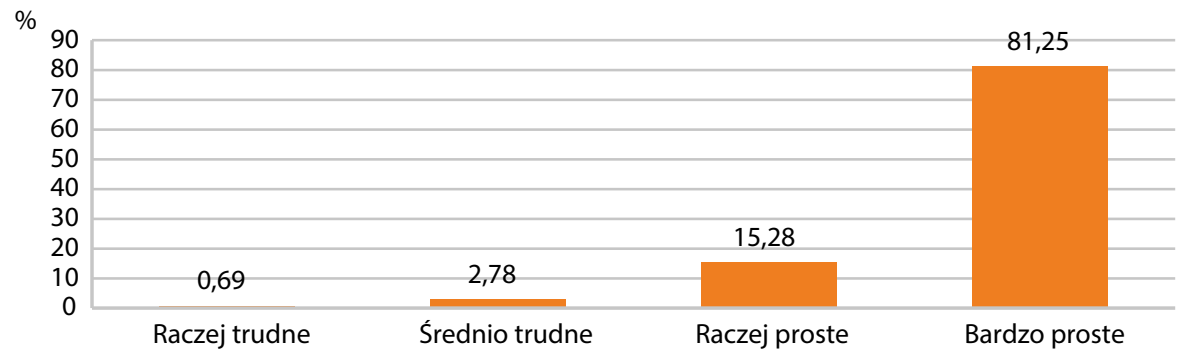

Jak skomplikowane było zainstalowanie oprogramowania?

Rysunek 7.4. Ocena skomplikowania zainstalowania oprogramowania

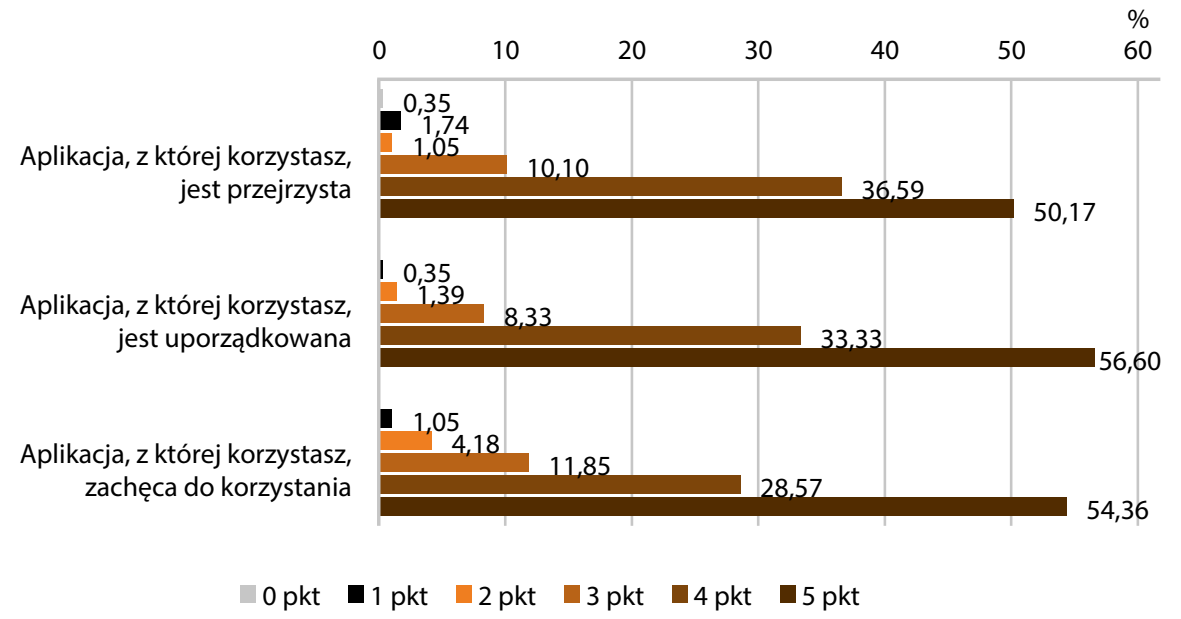

Rysunek 7.5. Ocena przejrzystości, uporządkowania i zachęcenia do korzystania z aplikacji 
Badani w większości byli zdania, że aplikacja jest raczej intuicyjna, a jej funkcje są łatwe w zapamiętywaniu (łącznie 94,10\%) (rysunek 7.6).

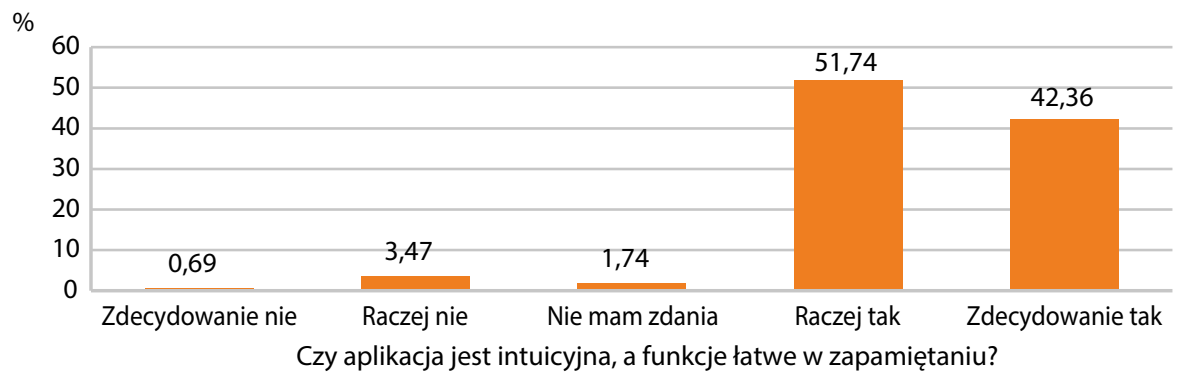

Rysunek 7.6. Ocena intuicyjności obsługi oprogramowania

Używana aplikacja służyła badanym zazwyczaj do kontroli domowego budżetu $(88,54 \%)$ i weryfikacji wydatków w ostatniego miesiąca $(86,11 \%)$, a następnie do sprawdzania salda rachunków $(48,26 \%)$ i planowania wydatków na kilka miesięcy $(45,83 \%)$ (por. rysunek 7.7$)$.

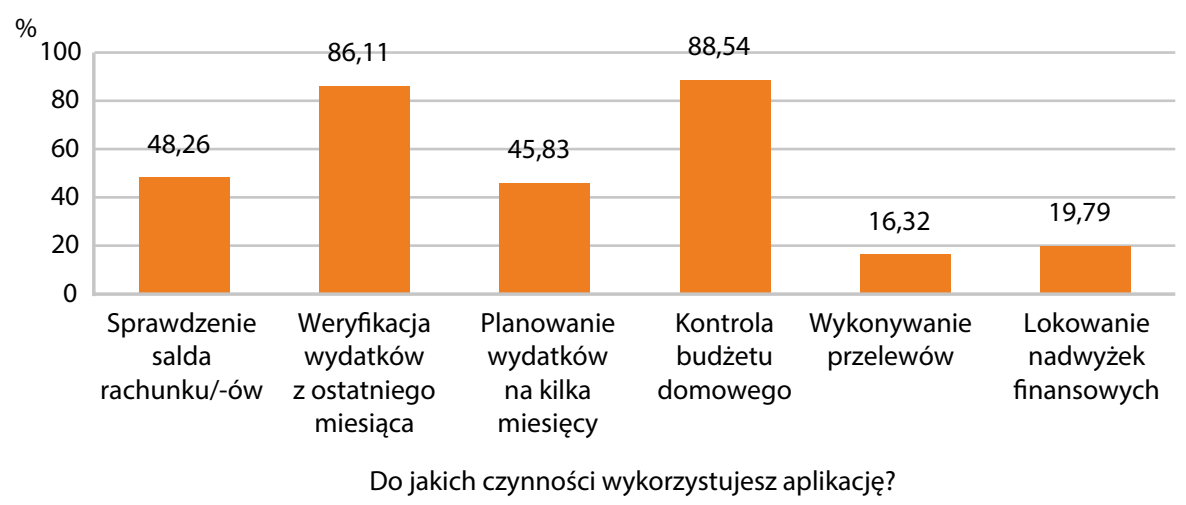

Rysunek 7.7. Czynności, do jakich wykorzystywana jest aplikacja

Aplikacje, z których korzystały badane osoby, posiadały zazwyczaj funkcję tworzenia budżetów $(79,51 \%)$ i samodzielną zmianę kategorii całego poniesionego wydatku (71,53\%). Najrzadziej natomiast aplikacje posiadały funkcję objaśnienia w zakresie nowych funkcjonalności aplikacji $(29,51 \%)$ importu danych finansowych z banków $(35,07 \%)$ (rysunek 7.8$)$. 


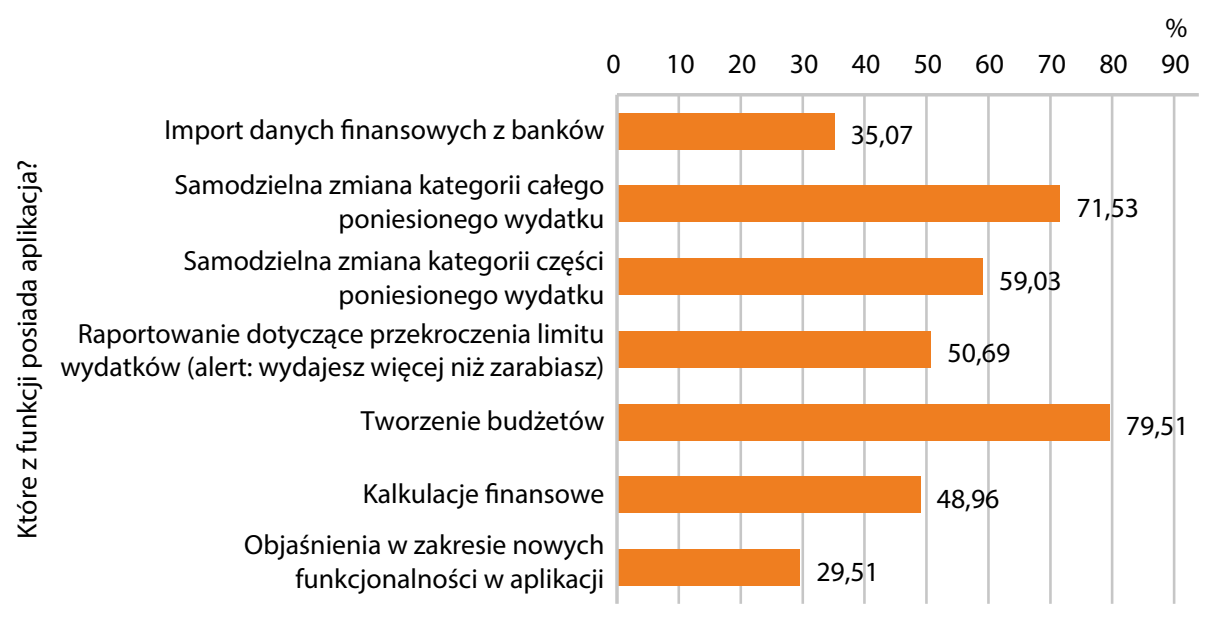

Rysunek 7.8. Funkcje posiadanej aplikacji

Osoby badane najczęściej przyznawały, że aplikacja pozwala na kontrolę nad codziennymi wydatkami $(93,40 \%)$ i nad budżetem $(66,67 \%)$, a także na planowanie przyszłych wydatków $(65,28 \%)$ i utrzymanie dodatniego salda na rachunku (50\%) (rysunek 7.9).

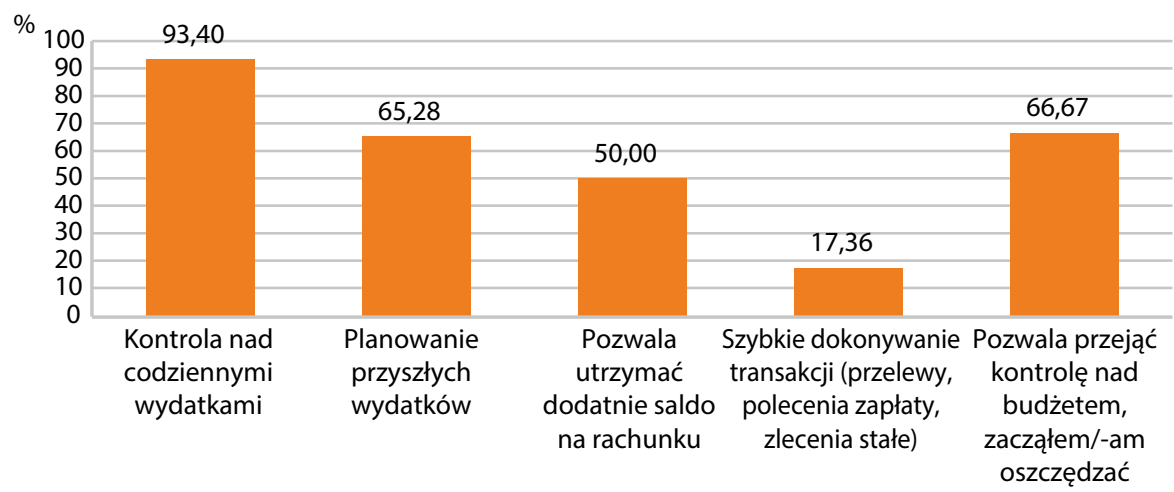

Które z potrzeb spełnia aplikacja?

Rysunek 7.9. Potrzeby, jakie spełnia aplikacja

Badani zazwyczaj byli zdania, że aplikacja nie ma błędów (21,33\%) lub nie wiedzieli o ich występowaniu (70,28\%) (rysunek 7.10). Osoby, które uważały, że aplikacja zawiera błędy, najczęściej wymieniały problemy z importem danych 
z konta i synchronizacją urządzeń oraz niemożliwość dodania w niektórych przypadkach własnych kategorii.

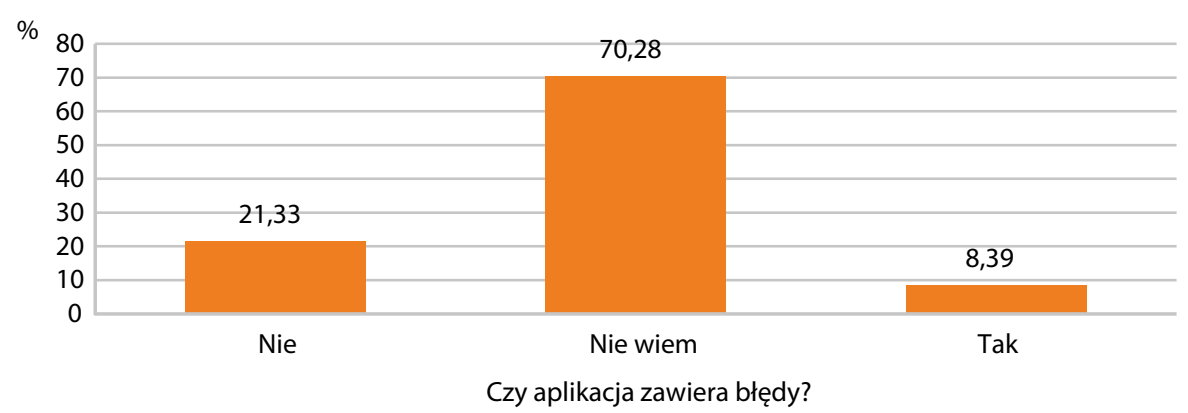

Rysunek 7.10. Ocena błędów aplikacji

Badani zazwyczaj byli zadowoleni z aplikacji i oceniali ją na 8-10 pkt, a średnia ocen wyniosła 8,42 pkt (rysunek 7.11). Również prawdopodobieństwo polecenia aplikacji było wysokie i średnio oceniane na 8,30 pkt (rysunek 7.12).

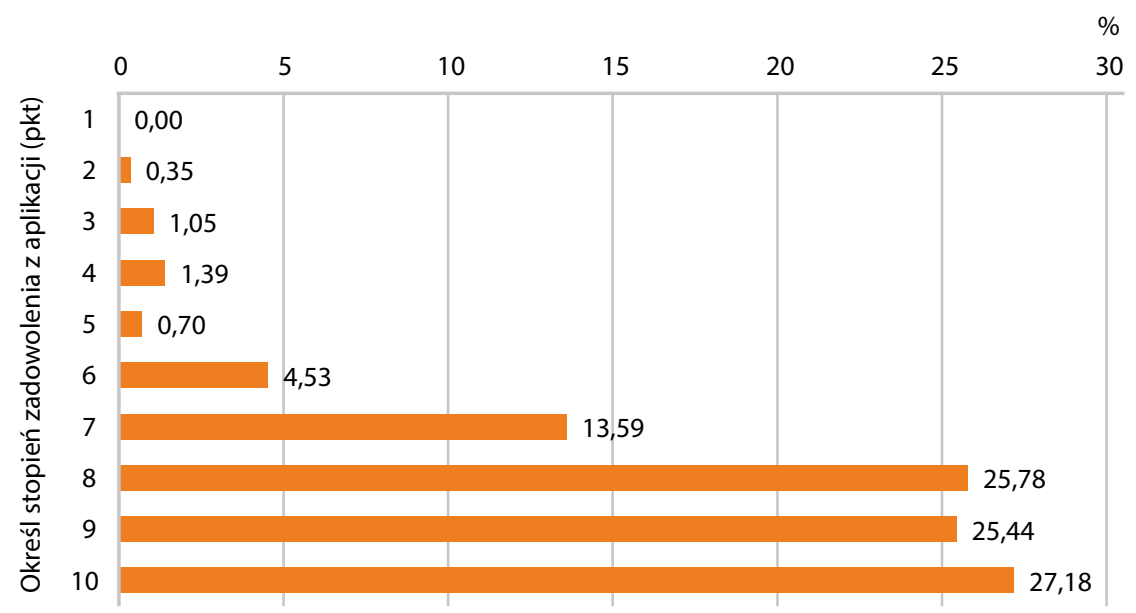

Rysunek 7.11. Ocena stopnia zadowolenia z aplikacji

Główną wymienianą korzyścią z użytkowania aplikacji była kontrola nad wydatkami (91,01\%), a następnie wyrobienie nawyku oszczędzania (71,53\%), wspieranie decyzji finansowych $(55,21 \%)$ i bezpieczeństwo finansowe poprzez bieżącą kontrolę salda rachunku (rysunek 7.13). Jako braki aplikacji badani wymieniali 


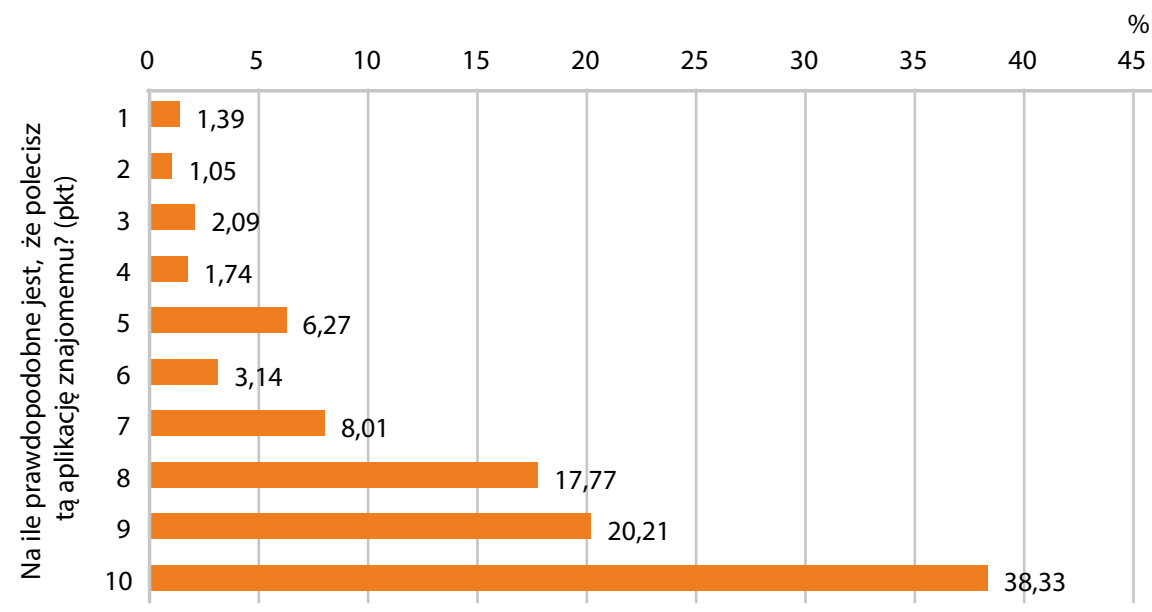

Rysunek 7.12. Prawdopodobieństwo polecenia aplikacji

natomiast brak możliwości wykonywania przelewów i integracji w bankiem, brak możliwości ustalenia podbudżetów, niemożliwość skanowania dokumentów, a także brak kursu walut.

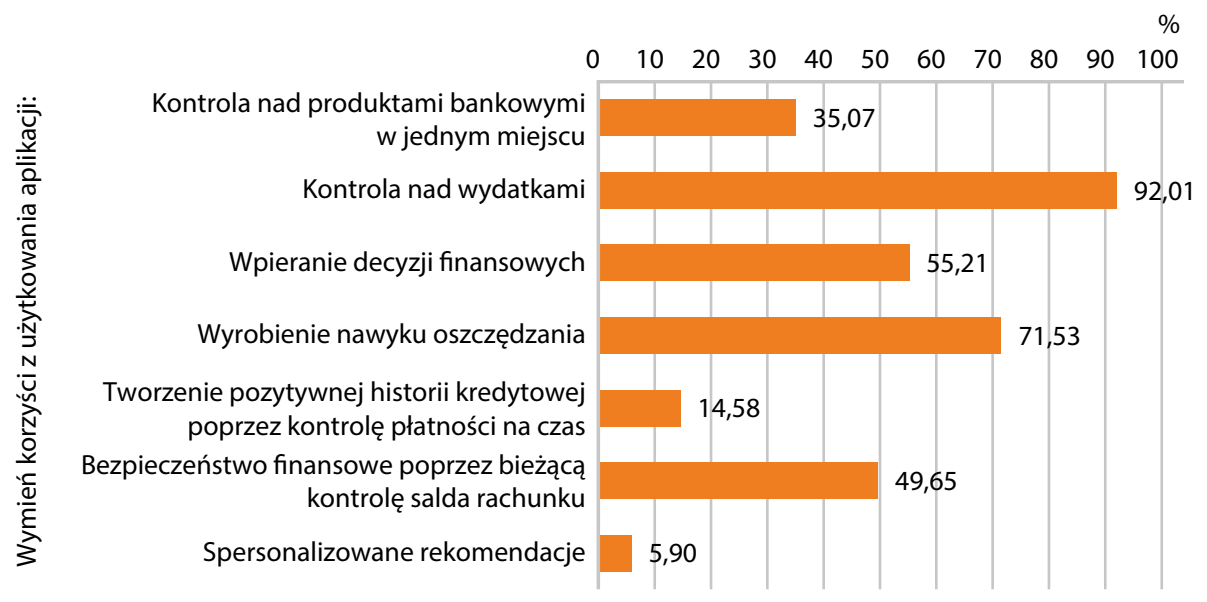

Rysunek 7.13. Ocena korzyści korzystania z aplikacji

Osoby badane zazwyczaj były zdania, że aplikacja pomogła im w zarządzaniu finansami w sytuacji samoizolacji, kwarantanny oraz pracy zdalnej (rysunek 7.14). 


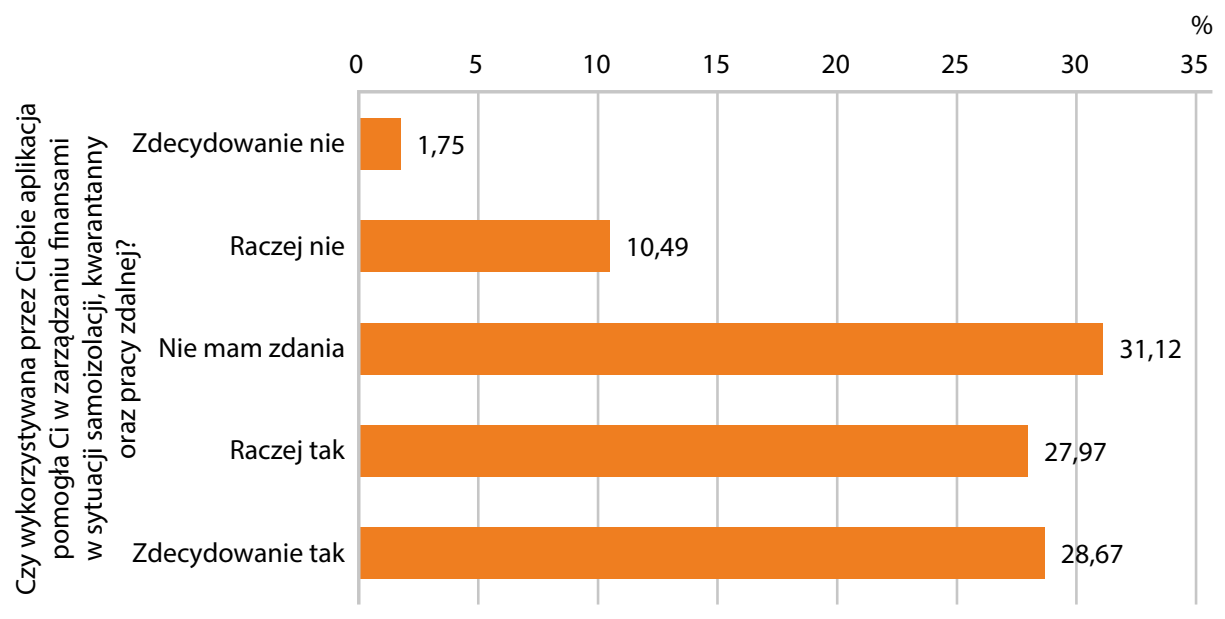

Rysunek 7.14. Wykorzystywanie aplikacji w czasach samoizolacji

Zdaniem badanych osób obszarami wymagającymi aktualizacji oraz lepszego dopasowania do potrzeb w warunkach pandemii były bieżące rozliczenia i płatności $(47,80 \%)$, a następnie przesyłanie skanów dokumentów $(29,67 \%)$ i porady konsultanta $(28,02 \%)$ (rysunek 7.15$)$.

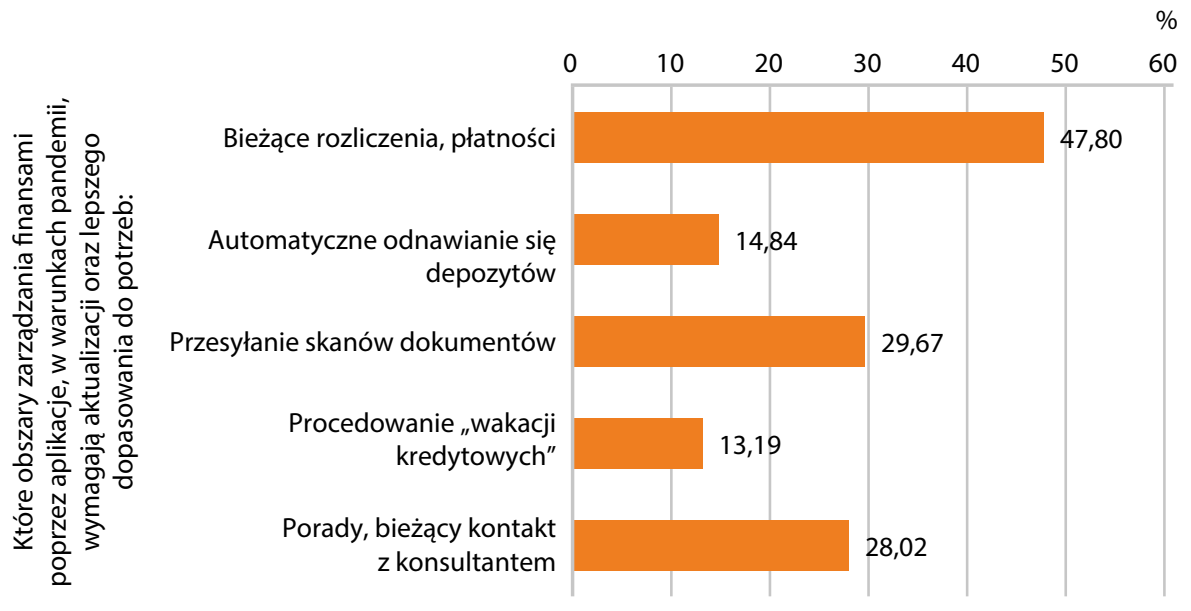

Rysunek 7.15. Ocena możliwości ulepszenia aplikacji

Pandemia COVID-19 najczęściej wpływała na badane osoby poprzez zmniejszenie dochodu $(32,99 \%)$ oraz zmniejszenie posiadanych oszczędności 
(25,69\%). Brak wpływu pandemii na budżet domowy deklarowało 17,71\% osób (rysunek 7.16).

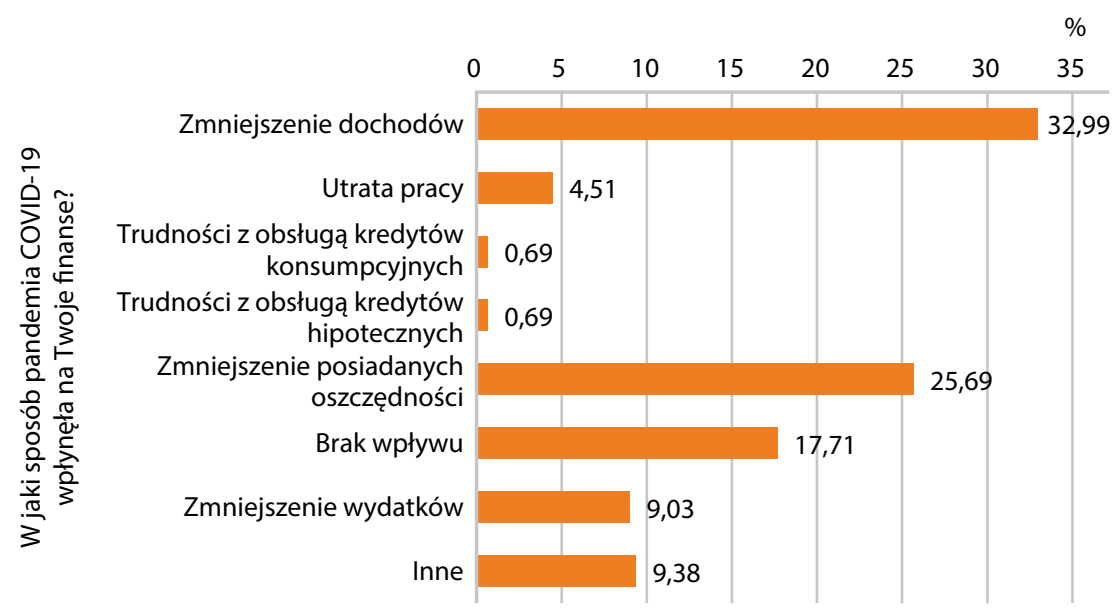

Rysunek 7.16. Wpływ pandemii na finanse domowe

\subsection{Podsumowanie}

Przedstawione $\mathrm{w}$ tym rozdziale badanie pierwotne wykazało, że $\mathrm{z}$ aplikacji do zarządzania budżetem domowym w czasie pandemii i samoizolacji najczęściej korzystali mężczyźni, a także osoby w wieku 26-35 lat. Kobiety częściej zauważały błędy w aplikacji do zarządzania budżetem i również gorzej oceniały chęć polecenia aplikacji znajomym, natomiast mężczyźni częściej byli zdania, że wykorzystywana aplikacja pomogła im w zarządzaniu finansami w sytuacji samoizolacji, kwarantanny oraz pracy zdalnej. Nie wykazano jednak związku oceny aplikacji $\mathrm{z}$ wiekiem $\mathrm{w}$ grupie badanej. W grupie osób korzystających $\mathrm{z}$ aplikacji przeważały osoby z wykształceniem wyższym. Osoby te również zdecydowanie lepiej oceniały aplikację, uważały, że jest ona przejrzysta i łatwa w obsłudze oraz częściej poleciłyby ją znajomym. Wykazano, że miejsce zamieszkania i dochody badanych osób były powiązane z oceną aplikacji. Najlepiej aplikację oceniały osoby mieszkające w dużych miastach i z wysokimi dochodami na osobę w gospodarstwie domowym.

Większość badanych osób korzystała z aplikacji mobilnie oraz przez stronę www, a następnie tylko z aplikacji mobilnej. Natomiast osoby, które były w mniejszości i używały aplikacji jedynie przez stronę www, oceniały aplikację najgorzej i niechętnie poleciłyby znajomym. Związki te były umiarkowanie silne. 
Zdecydowanie lepiej aplikację oceniały osoby korzystające z aplikacji niebankowych. Mimo opisanych różnic większość badanych osób przyznała, że aplikacja pomogła im w nadzorowaniu budżetu domowego w czasie samoizolacji i pracy zdalnej. Badani wymieniali sporo zalet aplikacji przy małej liczbie wad.

Pandemia SARS-CoV-2 stała się powodem do stwierdzenia luk w zdalnej obsłudze klienta, jak słabe dopasowanie do potrzeb bieżących rozliczeń i płatności, brak możliwości skanowania dokumentów oraz brak porad i bieżącego kontaktu z konsultantem. Przeprowadzone badanie w warunkach społecznej izolacji pozwala na wskazanie szans i zagrożeń dla dostawców usług wspomagających zarządzanie finansami, szczególnie w obszarze oferowanych narzędzi. Ocena użyteczności aplikacji PFM daje przestrzeń do ich dostosowania do zmieniających się potrzeb konsumentów. Podjęta problematyka wymaga dalszego, poznawczego pogłębienia.

\section{Bibliografia}

Albertazzi, D. (2018). Rebulding personal financial management in 2018: What banks need to know. Alite.

Badanie Moje ING. (2016). Zwyczaje platnicze Polaków. Pobrane z https://www.ing. $\mathrm{pl} /$ fileserver/item/1122151

Barembruch, A. (2013). Bankowość detaliczna a nowoczesne narzędzia wspomagające zarządzanie finansami osobistymi. Zarządzanie i Finanse, 2, 1, 34-46.

Beckett, A., Hewer, P. i Howcroft, B. (2000). An exposition of consumer behaviour in financial services industry. Marketing International Journal of Bank, 18/1, 15-26. https://doi.org/10.1108/02652320010315325

Blackwell, R. D., Miniard, P. W. i Engle, J. F. (2005). Consumer behaviour. Cincinnati: South-Western College Publishing.

Buettner, R. (2017). Predicting user behaviour in electronic markets based on personality-mining in large online social network. A personality-based product recommender framework. Electronic Markets, CrossMark, 27, 247-264. https://doi.org/10.1007/ s12525-016-0228-z

Cichowicz, E. (2016). Wykorzystanie nowoczesnych technologii przez instytucje finansowe w procesie przeciwdziałania wykluczeniu finansowemu. Annales. Etyka w Życiu Gospodarczym, 19, 1, 71-82.

Dorfleitner, G., Hornuf, L., Schmitt, M. i Weber, M. (2017). FinTech in Germany. Springer International Publishing AG.

Farah, P., Macaulay, J. i Ericsson, J. (2010). The next growth opportunity for banks. Survey Report. CISCO internet business solutions group. Pobrane $\mathrm{z}$ https://www.cisco.com/c/ dam/en_us/about/ac79/docs/fs/nextgrowthopportunityforbanks.pdf

Gafrikova, V., Szczesny, W. i Odrzygóźdź, Z. (2015). Online personal finance management applications. Information Systems in Management, 4, 1, 39-52.

Gawron, O. (2019). Otoczenie regulacyjne sektora Fintech na przykładzie Dyrektywy PSD2 i wybranych ustaw krajowych. Finanse i Prawo Finansowe, 4(24), 49-65. 
Górna, S. i Warchlewska, A. (2018). Nowoczesne technologie jako czynnik konkurencji na lokalnych rynkach usług bankowych (na przykładzie Gospodarczego Banku Spółdzielczego Międzyrzecz). Optimum. Economicum Studies, 1(91), 283-305.

Haikel-Elsabeh, M., Nouet, S. i Nayaradou, M. (2016). How personal finance management influences consumers' motivations and behavior regarding online banking services. Digiworld Economic Journal, 103.

Madir, J. (Ed.). (2019). FinTech: Law and regulation. Edward Financial Law and Practice.

Mazurek, K. i Maz, K. (2019). Human vs. artificial intelligence - A consumer behavioral study on advice taking among gen Y, master thesis submitted to the Barcelona School of anagement in partial fulfilment of the requirements for the degree of masters of science in management at Universitat Pompeu Fabra. https://doi.org/10.13140/ RG.2.2.11214.20807

Milic-Czerniak, R. (2019). Rola fintechów w rozwoju innowacji finansowych. W: K. Marchewka-Bartkowiak (red.), Innowacje i nowe technologie $w$ finansach. Studia BAS, 57(1). https://doi.org/10.31268/studiabas.2019.03

Musiał, M. (2015). Zastosowanie instrumentów zarządzania finansami osobistymi w polskich gospodarstwach domowych. Kwartalnik Kolegium Ekonomiczno-Społecznego. Studia i Prace, 4, 3, 233-243.

Nielsen, J. (2012). Usability 101: Introduction to usability. Pobrane z https://www.nngroup. com/articles/usability-101-introduction-to-usability/

Nitin, B., Abhilas, D., Aishwarya, D., Lipsa, D., Siddharth, M., Supriyo, G. (2019). Robo-advisory: An intestor's perception. International Journal of Psychosocial Rehabilitation, 23(3), 1-11. https://doi.org/10.37200/IJPR/V23I3/PR190376

Omarini, A. E. (2018). Banks and fintechs: How to develop a digital open banking approach for the bank's future. International Business Research, 11, 9, 23-36.

PFM na Zachodzie. Bank, 7-8. Pobrane $\mathrm{z}$ https://alebank.pl/wp-content/uploads/2013/07/ bank.2013.07-08.068-069.pdfRaport e-Izby. (2017). Portfel Polaka. Ptatności, budżet, inwestycje i oszczędności. Pobrane z https://eizba.pl/wp-content/uploads/2018/07/PortfelPolaka_1.pdf

RCS. (2012). Using technology to help manage finances. Pobrane z https://www.ebri.org/ docs/default-source/rcs/6_fs-06-rcs-12-fs6-tech.pdf?sfvrsn=62e5302f_2

Samsel, A. (2019). Planowanie jako element zarządzania budżetem gospodarstw domowych. Rozprawy ubezpieczeniowe. Konsument na Rynku Usług Finansowych, 31(1), $57-68$.

Świeszczak, K. (2017). Zaufanie w świecie finansów w obliczu rozwoju technologii na przykładzie banków i sektora FinTech. Bezpieczny Bank, 2, 143-158.

Uryniuk, J. (2012, 21 grudnia). Aplikacja pomaga wydawać mniej. NBP. Cykl dodatków w ramach programu edukacji ekonomicznej. Dziennik Gazeta Prawna.

Waliszewski, K. (2014). Personal financial planning (personal financial management) with the participation of financial advisers - significance for households and the economy. Management Issues, 12(48), 204-221. https://doi.org/10.7172/1644-9584.48.11

Waliszewski, K. i Warchlewska, A. (2020a). Attitudes towards artificial intelligence in the area of personal financial planning: a case study of selected countries. Entrepreneurship and Sustainability Issues, 8(2), 399-420. https://doi.org/10.9770/jesi.2020.8.2(24) 
Waliszewski, K. i Warchlewska, A. (2020b). Financial technologies in personal financial planning: robo-advice vs. human-advice. Ruch Prawniczy, Ekonomiczny $i$ Socjologiczny, LXXXII, 4, 303-318. https://doi.org/10.14746/rpeis.2020.82

Waliszewski, K. i Warchlewska, A., (2020c). W zarządzaniu finansami omijamy banki. Pobrane z https://www.bankier.pl/wiadomosc/W-zarzadzaniu-finansami-omijamy-banki-8005688.html

Warchlewska, A. i Waliszewski, K. (2020). Who uses robo-advisors? The Polish case. European Research Studies Journal, XXIII (Special 1), 97-114.

Węglewski, M. (2019). Przyjazny Bank „Newsweeka”. [WYNIKI]. Pobrane z https://www. newsweek.pl/biznes/przyjazny-bank-newsweeka-2019-wyniki-rankingu/2nx2s1p

Włodarczyk-Śpiewak, K. (2011). Nowoczesne technologie-wyzwanie dla współczesnych konsumentów. Studies \& Proceeding of Polish Assiociation for Knowledge Management, 51, 143-152. 